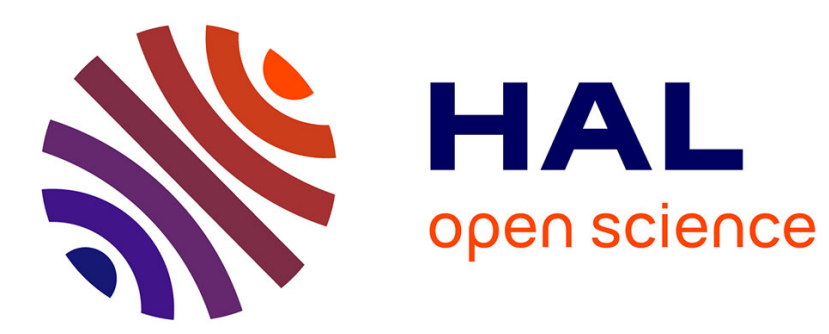

\title{
PHYSIOLOGY OF THERMAL PANTING IN BIRDS
}

\author{
S.-A. Richards
}

\section{To cite this version:}

S.-A. Richards. PHYSIOLOGY OF THERMAL PANTING IN BIRDS. Annales de biologie animale, biochimie, biophysique, 1970, 10 (hs2), pp.151-168. hal-00896587

\section{HAL Id: hal-00896587 https://hal.science/hal-00896587}

Submitted on 1 Jan 1970

HAL is a multi-disciplinary open access archive for the deposit and dissemination of scientific research documents, whether they are published or not. The documents may come from teaching and research institutions in France or abroad, or from public or private research centers.
L'archive ouverte pluridisciplinaire HAL, est destinée au dépôt et à la diffusion de documents scientifiques de niveau recherche, publiés ou non, émanant des établissements d'enseignement et de recherche français ou étrangers, des laboratoires publics ou privés. 


\title{
PHYSIOLOGY OF THERMAL PANTING IN BIRDS
}

\author{
S.-A. RICHARDS \\ Wye College, University of London. \\ near. Ashford, Kent (Great-Britain)
}

\section{INTRODUCTION}

Almost all important aspects of physiological thermoregulation involve the integration of complex bodily changes influencing the fundamental physical processes which govern heat exchange between an object and its environment. In practice the characteristic deep body temperature of a species represents a balance established between heat generated by metabolic and muscular activity on the one hand, and that dissipated to the environment by conduction, convection, radiation, and evaporation of moisture on the other.

With respect to the particular problems of maintaining thermal homeostasis in warm conditions, birds are notable for their high body temperatures, typically some $3-4^{\circ} \mathrm{C}$ above mammals, their lack of sweat glands, and the remarkable efficiency of the thermal insulation provided by feathers. While the first of these undoubtedly confers an advantage relative to mammals, the others imply that heat loss by evaporation from the general body surface must be slight. Thus, although under moderate conditions, with ambient temperature less than that of the body, a degree of heat dissipation can occur by physical transfer to the air or ground, a further increase in the temperature of the environment will reduce the efficiency of these processes and throw more and more emphasis on the only remaining mechanism, that of evaporative cooling from the respiratory tract. Indeed, when ambient temperature exceeds that of the body, such cooling becomes the sole avenue for heat loss. However, panting in the feathered bird may be considered a direct and efficient means of dissipating body heat by evaporation, for the heat of vaporization of every gram of water evaporated from the respiratory tract represents virtually the same quantity of heat removed from the body core ; by contrast, the heat of vaporization of water evaporated from any external surface is derived in part from the environment as well as the core. Nevertheless, panting is not necessarily a more efficient heat-loss mechanism than sweating; phylogenetically it is the more primitive form, while the considerable respiratory adjustments involved always represent at least a potential danger to the maintenence of a normal acid-base equilibrium. 
The present review is restricted to three main objectives :

I. To summarize the available data on the mechanism and efficiency of thermal panting against a background of our present knowledge of avian respiratory function ;

2. To present the current information on the nervous control of polypnoea in birds as compared with that known for mammals;

3. To consider the effects of panting on the acid-base status of the blood.

The relevant mammalian work has been reviewed most recently by HARDY (I96I), Bligh (I966) and Hammei, (I968).

\section{I. - THE MECHANISM AND EFFICIENCY OF PANTING}

\section{A. - Respiratory parameters}

Observations on mammals have substantiated RICHET'S (I898) definition of polypnoea as a facilitated forms of fast and shallow respiration, but in birds, owing in part to the peculiar structure of the respiratory system, it has been by no means obvious that the rapid breathing movements which occur in hot conditions were invariably accompanied by a reduction in tidal volume. LASIEWSKI and BARTHOLOMEW (I966) defined avian panting as an increase in rate and amplitude of breathing movements, while SALT (Ig64) concluded after his survey of the literature that many species of birds increase the tidal volume as temperatures rise.

Until quite recently there was no quantitative information on this subject with the single exception of that by SAALFELD (I936), whose direct measurements on the

TABLE I

Respiratory volumes of pigeons at various air temperatures

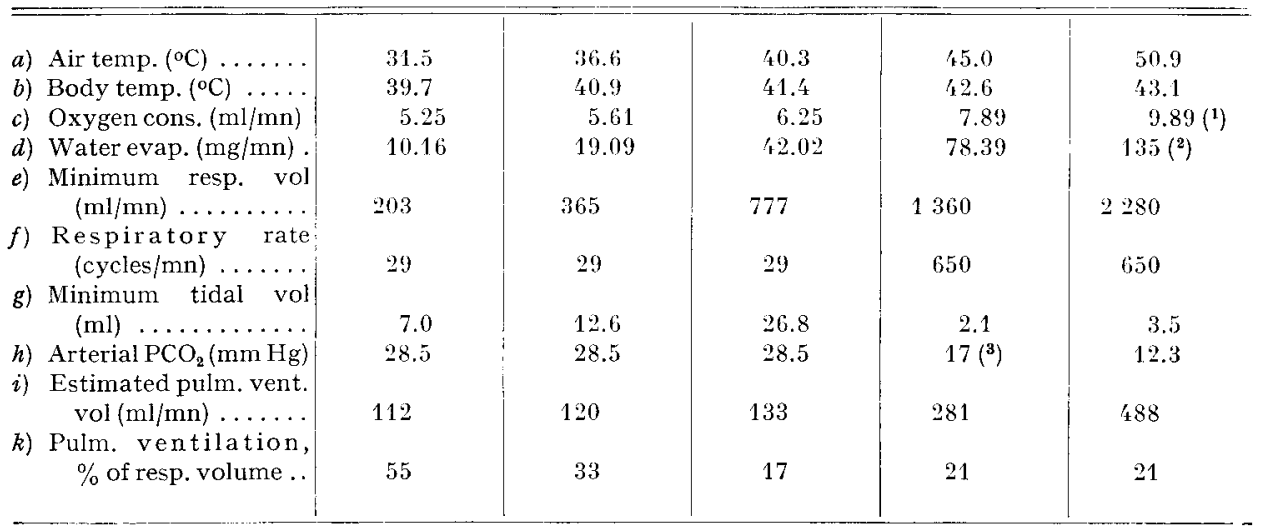

(1) Based on extrapolation of data from lower temperatures.

(2) Weight loss corrected for droppings and carbon dioxide loss.

$\left.{ }^{3}\right)$ Interpolated from mean values for 40.0 and $50.9^{\circ} \mathrm{C}$ air temperature.

(After Calder and Schmidt-Nielsen, 1966 ; courtesy Proc. Nat. Acad. Sci. and authors.) 
pigeon showed a decrease in tidal volume with increasing body temperature and respiratory frequency. SALT (I964) argued that this species could be exceptional and that its high rate of panting might indicate that evaporative cooling occurred high up in the trachea instead of in the lungs and air sacs as has generally been assumed to be the case in birds. While recent work on the pigeon and roadrunner (CAL,DER and SCHMIDT-NIELSEN, I966, I967) has confirmed the reduced tidal volume during panting on the basis of calculations of the minimum volume of air necessary to carry a measured amount of moisture evaporated (table I), FRANkEL, Hollands and WEISS (I962) have made direct measurements of respiratory air flow in the hyperthermic fowl using the Fleisch pneumotachograph and a tracheal cannula. Their results indicated a steadily declining tidal volume until a core temperature of about $44.0^{\circ} \mathrm{C}$, at which point a fall occured in respiratory rate and with it a secondary increase in tidal volume (fig. I). CALDER and SCHMIDT-NIELSEN (I966) estimated that this must also occur in the pigeon, so that the pattern observed in these birds appears strikingly reminiscent of the biphasic respiratory response to heat exposure described in various mammals (ANREP and HAMmoudA, I933; FINDLAy, I957; BIANCA, I958; HALES and WEBSTER, I967). A reduction in tidal volume was also observed during thermal panting in the fowl by ROMIJN and LOKHORST (I96I) and LINDSIEY and BURGER

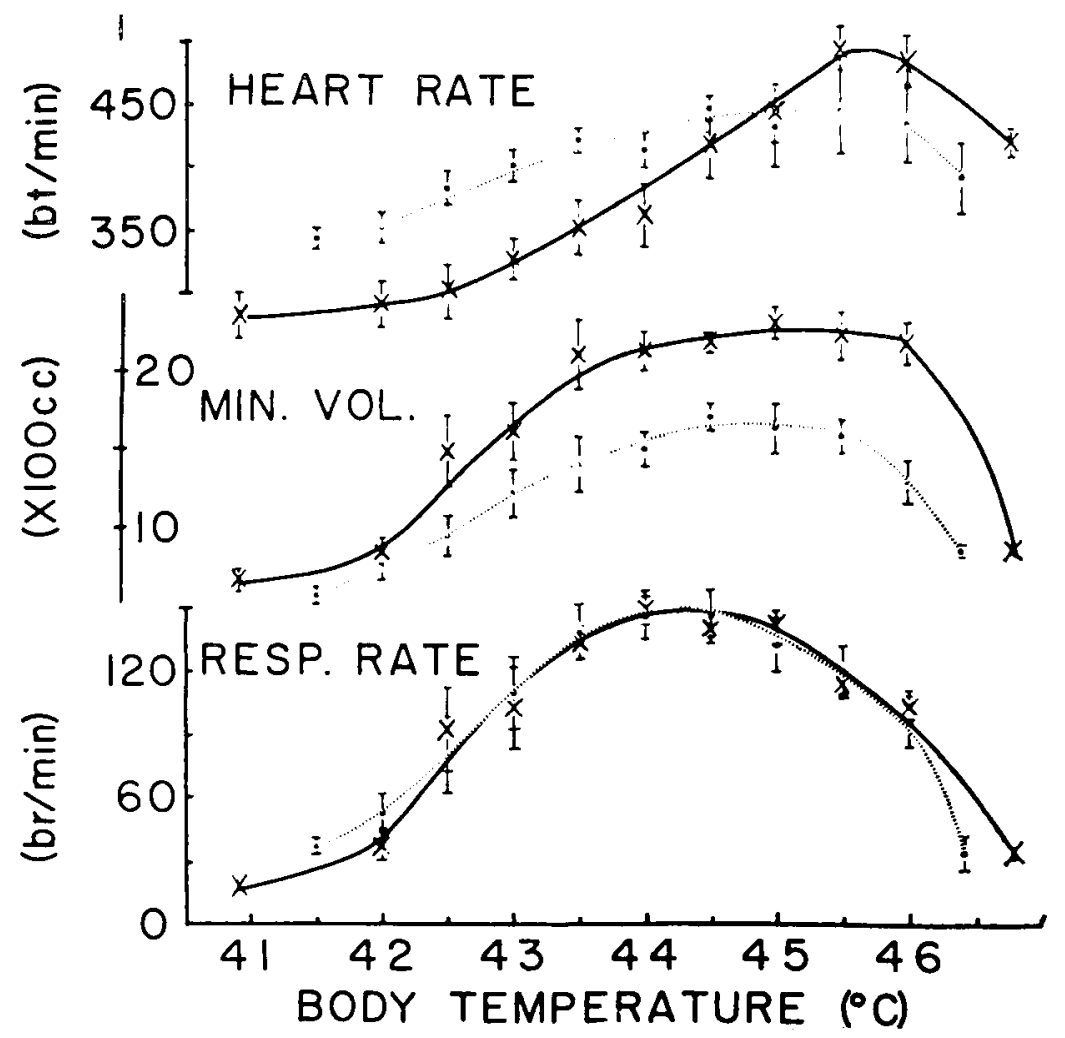

FIG. I. - Changes in respiration and heart rate with rising body temperature in adult male $(n=5)$ and female $(n=8)$ White Leghorn chickens

(After Frankel et al., Ig62; courtesy Arch. internat. Physiol. Bioch.) 
(I964), while RANDAII and Himstand (I939) were the first to note the secondary decline in frequency during prolonged exposure to heat in the same species. However, CRAWFORd and SchmidT-NiELSEN (I967) calculated that an increase in tidal volume must occur in the panting ostrich to account for the II-fold enhancement in evaporation seen under exposure to ambient temperature rising from $25^{\circ}$ to $5^{\mathrm{I}^{\circ} \mathrm{C}}$, during which time a constant rate of breathing $(45 / \mathrm{mn})$ was maintained.

CRAWFORD (I962), who found that the natural resonant frequency of the dog's respiratory system was $5.28 \perp 0.3 \mathrm{c} / \mathrm{s}$ as compared to the hoat-induced rate of $5.33 \pm 0.7 \mathrm{c} / \mathrm{s}$, was able to show in terms of respiratory impedance and maximum volume flow with least effort, the increased efficiency of panting at the resonant frequency. Among birds, the pigeon and roadrunner (CALDER and SCHMIDT-NiELSEN, 1967) and the ostrich (CRAWFORD and SCHMIDT-NIELSEN, I967) all seem to pant at characteristic fixed frequencies independent of rectal temperature, whereas in the tawny-frogmouth (LASIEWSKI and BARTHOLOMEW, I966) respiratory rate increases linearly with body temperature up to a maximum of Ioo breaths/mn at $42.5^{\circ} \mathrm{C}$. The fowl appears to fall into the latter category, and this is why estimates of panting frequency have varied widely. Most observers reported rates of not more than 220 breaths/mn (RoMijn and LokHORST, I96I; RANDALL, I943; FRANKEL et al., I962 ; WHITTOW, STURKIE and STEIN, I964 ; RICHARIS, I968 $a, b$ ), but LINSLEY and BURGER (I964) found panting frequency to reach more than 250 breaths/mn in each of their White Leghorn cocks, while HuTchinson (I954 a) reported a mean of 286/min in Brown Leghorn undersevere heat stress and humidity, and claimed rates of over $400 /$ min for fully acclimatized hens (Hu'TCHINSON, I954 b).

Another aspect of this problem is that panting and gular fluttering are, in effect, two quite different phenomena and have not always been adequately distinguished. Thus, in most species the movements of the thorax and the gular pouch are synchronized, but in others, for example the White pelican (BARTHOLOMIw, DAwson and O'NEIL, I953) the two processes occur independently. Some birds pant without gular flutter (e. g. starlings, LAsiEwski, ACosTA and BERNSTEIN, Ig66 b) and others may flutter the gular region without characteristic panting (e. g. poor-will, LASIEWSKI and BARTHOLOMEW, I966). In addition, the common nighthawk (LASIEWSKI and DAwSON, I964) flutters at a relatively constant rate, presumably the resonant frequency of the hyoid apparatus, while in other birds (bob-white and Gambel's quail, LASIEWSKI and KEES, quoted in LASIEWSKI et al., I966 b) the rate of gular flutter increases markedly with rising heat load.

Despite a reduction in tidal volume, the considerable acceleration in respiratory rate (20-fold in the pigeon, CALDER and SCHMIDT-NIELSEN, I966) during panting would be expected to increase the minute volume substantially. SAALFELD (I936) found in the dove a maximum of $635 \mathrm{ml} / \mathrm{mn}$ at a respiratory frequency of 490 breaths/mn, as compared with $185 \mathrm{ml} / \mathrm{mn}$ at 46 breaths/mn during normothermia. CALDER and SCHMIDT-NIELSEN (Ig66), however, considered the former figure too low, since their own calculations (table I) indicated a maximum minute volume of $228 \mathrm{om} / \mathrm{mn}$ at a panting frequency of $650 / \mathrm{mn}$ at body temperatures similar to those in Saalfeld's experiments $\left(43 \cdot \mathrm{I}^{\circ} \mathrm{C}\right)$.

In the fowl, Romijn and LoKHorst (I96I) estimated from their data on total water loss and the difference in water content of inspired and expired air, an increase of from I 300 to $4800 \mathrm{ml} / \mathrm{mn}$ in the Blue North Holland Cock and from 750 to 
$4900 \mathrm{ml} / \mathrm{mn}$ in the hen at ambient temperatures of $22^{\circ}$ and $37^{\circ} \mathrm{C}$ respectively. FRANKEL et al. (Ig62) found by direct measurement an increase of minute volume with body temperature from $655 \mathrm{ml} / \mathrm{mn}$ in males and $568 \mathrm{ml} / \mathrm{mn}$ in females at normal body temperatures to a maximum of 2300 and I $700 \mathrm{ml} / \mathrm{mn}$ respectively at rectal temperatures of $44 \cdot 5-45 \cdot 5^{\circ} \mathrm{C}$. Maximum respiratory rate was attained at about $I^{\circ} \mathrm{C}$ lower, so that for some time, i. e. until the final inflection, the minute volume was maintained by an increase in tidal air (fig. I).

\section{B. - Air sacs}

That the air sacs play an important part in evaporative cooling has been supposed ever since ZEUTHEN (I942) pointed out that their size and distribution in birds can only be rationalized in connection with the requirement for dissipation of excess heat during flight. According to SALT (I964), most of the evaporation probably occurs in the anterior thoracic, interclavicular and cervical sacs ; the posterior thoracic and abdominal sacs seem to function as bellows during normal breathing and panting in many birds (KING and FARNER, I964), and possibly also represent in the non-flying bird the primary surfaces for increased evaporation. In some species the anterior air sacs may, in addition, be ventilated during exposure to ambient heat, while in others evaporative cooling appears to have reached its ultimate development where the tidal air ventilates the highest levels of the trachea, as in the pigeon, or the buccal cavity itself, as in the poor-will (SALT, I964). Exactly how the differential ventilation of the air sacs may be controlled under various conditions, perhaps by changes in the diameter of the parabronchi resulting from contraction of their smooth musculature (FISCHER, I905; ZEU'THEN, I942 ; CALDER and SCHMIDT-NIELSEN, IgC6;, remains as one of the major functional problems presented by the anatomy of the avian respiratory system.

\section{C. - Cooling efficiency of panting}

The physical principles governing evaporative cooling in birds have been reviewed in recent years by several authors (HUTCHINSON, I954 a, b; KING and FARNER, I96I, I964; SALT, I964) and no useful purpose would be served by repeating their approach and conclusions. Suffice it to say that, at normal physiological temperatures, the rate of cooling per unit evaporating surface and tidal air is, in essentials, a linear function of the difference between the water vapour pressure of the evaporating surface and that of the environmental air. The vapour pressure of the air is dependent upon the absolute humidity, so that a bird can evaporate moisture even in a saturated atmosphere, as long as the ambient temperature is below that of the respiratory passages. Most authors have assumed that the temperature of the evaporating surfaces is nearly equal to deep body temperature, and this, being high, must give birds a greater independence of humidity than is the case with panting mammals.

It has been widely accepted that in small birds only about half the heat produced by metabolic activity can be lost by evaporative cooling (KAYSER, I930; KENDEIGH, I944; WALLGREN, I954 ; BARTHOLOMEW and CADE, I963; DAwSON and SCHMIDTNIEI,SEN, I964; KING and FARNER, I964; LASIEWSKI, I964). An exception to this 


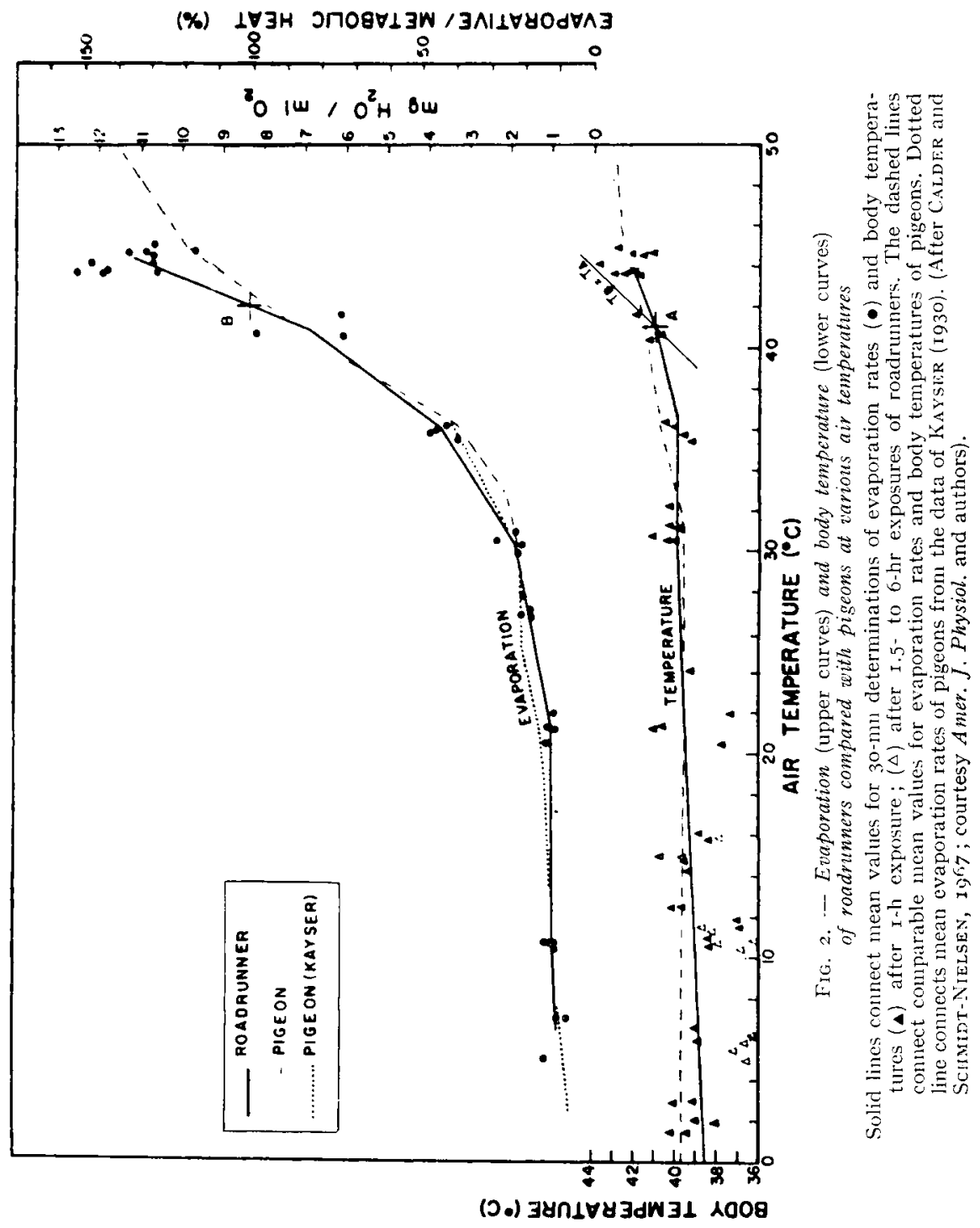


appears to be the poor-will which has been shown capable of dissipating I6o p. Ioo of its metabolic heat, although this may be a reflection of its low metabolic rate, rather than any unusual evaporative capacity (BARTHOLOMEW, HUDSON and HOWELI, I962). Theoretical considerations indicate that a few other goatsuckers (CowLES and DAWSON, I95I) as well as the sand grouse (SALT and ZEUTHEN, I960) may be equally efficient. Recently, however, LASIEWSKI et al. (I966 a) concluded that many of the earlier experiments were misleading owing to the use of relatively low air flow rates in the open-flow methods of determination of evaporative cooling, and demonstrated that a wide variety of small birds could maintain their body temperatures below ambient temperatures of $44-46^{\circ} \mathrm{C}$ for periods from I-4 hours through evaporative cooling. It was also shown in the pigeon, roadrunner and ostrich (CAL,DER and SCHMIdT-NIELSEN, I966 ; CRAWFORD and SCHMIdT-NiELSEN, I967) that environmental temperatures as high as $5 \mathrm{I}^{\circ} \mathrm{C}$ could be tolerated without excessive hyperthermia ; evaporative cooling accounted for more than metabolic heat and the excess represented heat gain from the environment (fig. 2). The fowl appears to be somewhatless efficient (Hutchinson, I954 $a, b$; Romijn and Lokhorst, I96I ; Es HAd, I969), and the relatively poor performance may prove to be related to the increased energy cost of non-resonant panting (CRAWFORD, I 962). In any event, tolerance of several degrees of hyperthermia, such as occurs in the fowl, does appear to be a regular feature among many avian species (DAwSON, I958; BARTHOLOMEW, I960).

\section{II. - CENTRAL AND PERIPHERAI,}

\section{NERVOUS CONTROL OF PANTING}

The early work of RogERS (I9I9) and RogERS and WHEAT (I92I) showed that decerebration or thalamic cauterization in the pigeon abolished all ability to control body temperature, but that careful removal of the cerebral hemispheres alone, leaving the thalamus intact, or lesions in the dorso-medial grey matter of the diencephalon which did not completely separate the forebrain from the mesencephalon, left the normal responses to heat exposure completely or partially intact. ROGERS (I928) found, in addition, that the application of ice or cold air to the exposed thalamus in the region of the third ventricule caused an increase in body temperature and in some cases the onset of panting when the former had risen above $43.0^{\circ} \mathrm{C}$. These investigations found support in the important paper by SAALFELD (I936) who not only described a centre in the medulla governing normal respiration in the pigeon, butalso found a specific panting centre in the anterior dorsal midbrain, destruction of which eliminated panting and left respiration solely under the control of the medullary centre. SAALFEID showed that the direct application of heat to the panting centre initiated rapid breathing, while cooling of the centre, even in the hyperthermic pigeon, abolished the previously established polypnoea. Similarly, panting ceased during intense electrical stimulation of the central stump of the cut vagus or when the pigeons breathed gas mixtures rich in carbon dioxide or poor in oxygen, suggesting that the normal sensitivity of the medullary neurones remained largely unaffected. In contrast, injections of lobeline (a central nervous system stimulant) could induce apparently normal panting after complete transection of the diencephalon from the medulla. As a result of these experiments, SAALFELD concluded that thermal polypnoea, 
although normally under the control of the specific panting centre, could in some circumstances, be maintained by the medullary centre alone, and this view was further supported when Sinha (I959) demonstrated with pigeons the involvement in panting of a $20 \mathrm{~mm}^{2}$ area of the dorsal midbrain lying between the optic lobes. Electrical stimulation of this region induced rapid respiration, although the rhythm was slower than the heat-induced panting. In the same species the importance of discrete brain structures was confirmed by AKERMAN, ANDERsson, FABricius and Svexsson (I960) who elicited panting by electrical stimulation of the anterior hypothalamus and pre-optic areas, thus corroborating the numerous observations of this type on mammals (BLIGH, I966).

Confirmatory results were also obtained in the fowl by the use of the complementary technique of selective lesions in the hypothalamus (FELDMAN, LARSSON, Dimick and LEPKOVSKx, I957; Kanematsu, Kir, Sonoda and KaTo, I967), so that our present knowledge of the intrinsic factors controlling heat loss through respiratory activity indicates that thermosensitive neurones in the ventral diencephalon can profoundly influence the activity of the medullary centre and that this influence may be exerted by way of a specific panting centre in the dorsal diencephalon or midbrain. Recent experiments by SAINT PAUL, and ASCHOFF (I968) suggest that the temperature fluctuations which can be recorded deep in the brain of conscious chickens (and which are often mirrored by fluctuations in skin temperature) may reflect changes in cerebral blood flow rather than of blood temperature. And whether the panting centre will ultimately prove analagous in function to the pontine pneumotaxic centre of mammals also remains to be seen; it is the latter which is widely considered the receptor for descending impulses from the hypothalamus, and the instigator through its connections with the medullary centres, of the increase in respiratory frequency observed in conditions of heat stress (WANG and NGAI, I964).

The apparent similarity in function between the pneumotaxic centre and vagal afferents has often been noted in respiratory physiology (COMroz, I965), one of the most prominent vagal reflexes being concerned with the inhibition of maximal inspiration which thus results in an acceleration in rate of breathing by allowing expiration to occur earlier. In birds, the role of the vagus nerves in normal respiration has been investigated in recent years by SINHA (I958), FEDDE, BURGER and KI'TCHELL, (I963 a, b) and RICHARDS (I969), and the more important earlier literature was reviewed by KInG (I966). During hyperthermia SAALFELI) (I936) and Sinha (I959) showed that bilateral vagotomy in pigeons had little effect on panting frequency despite the considerable reduction which always occurred at normal body temperature. In the fowl, however, HiEstand and RANDALL (I942) and RANDALL and HIESTAND (I942) found that vagotomy inmediately abolished panting, and this has now been shown in the duck and quail (fig. 3). The presence of an effect similar to the Hering-Breuer inflation reflex of mammals has been demonstrated in the pigeon and fowl at normal body temperature, but not during thermal panting (Richards, I $968 \mathrm{a}$ ), and the relative weakness of the effect appears to support the contention of FEDDE et al. (Ig6I) that the reflex itself may not be important for the maintenance of normal respiratory rhythm. 'The peculiar anatomy of the respiratory passages in birds has led te several conflicting views of function (SAIT and ZEUTHEN, I96o) and it has yet to be confirmed that the normal volume changes in the avian lung are adequate to stimulate any stretch receptors that may be postulated. Such data 


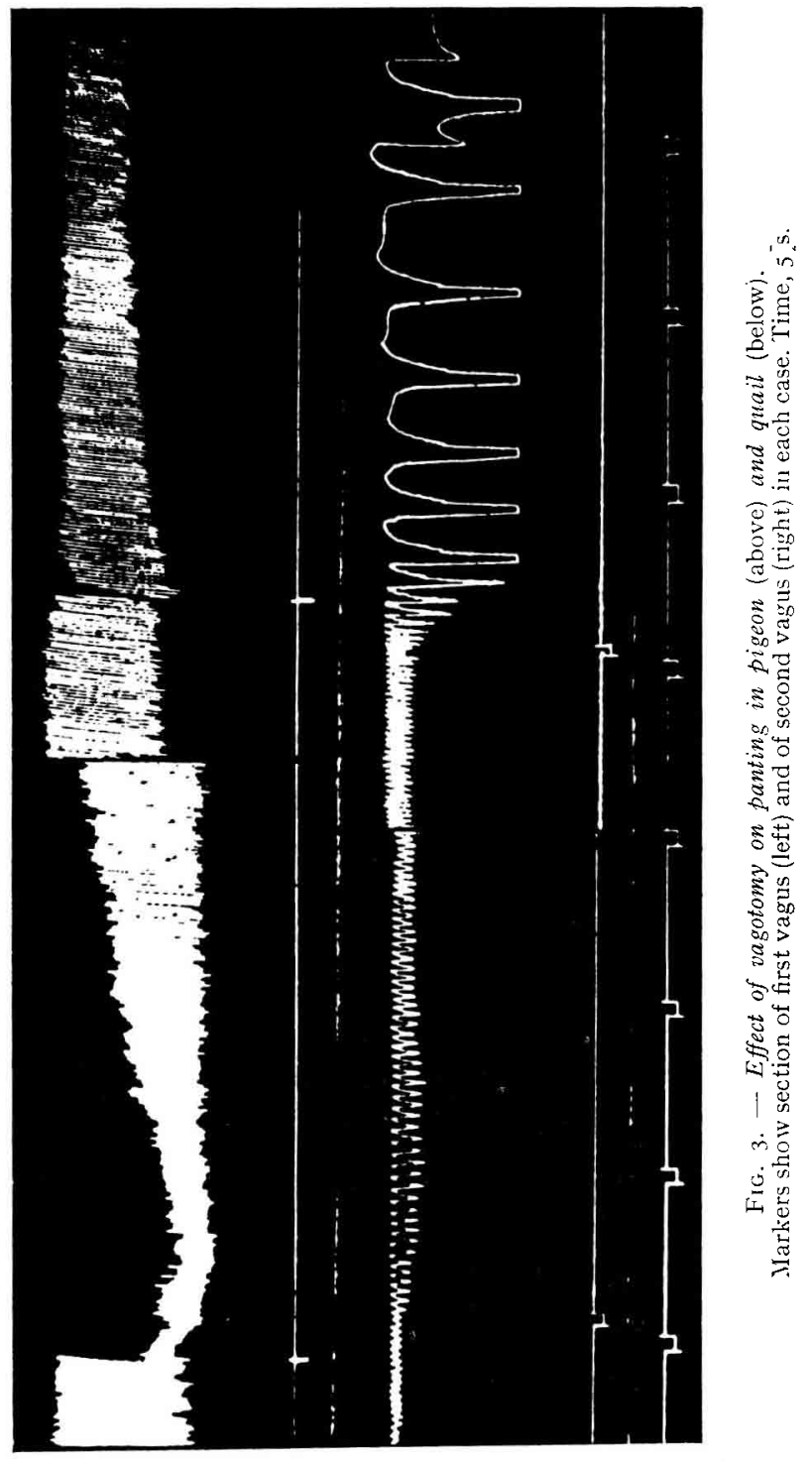


as are available at the present time seem to support the evidence of FEDDE et al. (I963 $b$ ) for the involvement of additional peripheral receptors, also innervated by branches of the thoracic vagus, in the maintenance of normal respiratory movements.

The recent demonstrations (RICHARDS, I968) that, following double vagotomy, constant afferent vagal stimulation could not only maintain normal respiration in the fowl, but also permit the change to panting in response to rising body temperature, indicates some form of mobilization of central mechanisms during hyperthermia which, in contrast to those of the pigeon, do not apparently function in the absence of afferent vagal drive; some fowls continued to pant after subsequent withdrawal of the stimulus (fig. 4). Details of the neural integration of these aspects of respiratory control await further investigation but the precise nature of the afferent vagal stimulus to the respiratory centre seems to be a more important controlling factor than central or peripheral chemical stimuli (RICHARDS, I969). In practice, the overall facilitating influence of the vagal afferents on respiration in the fowl seems clear, and this effect is in all probability exerted on a basic firing rate of the medullary neurones of some

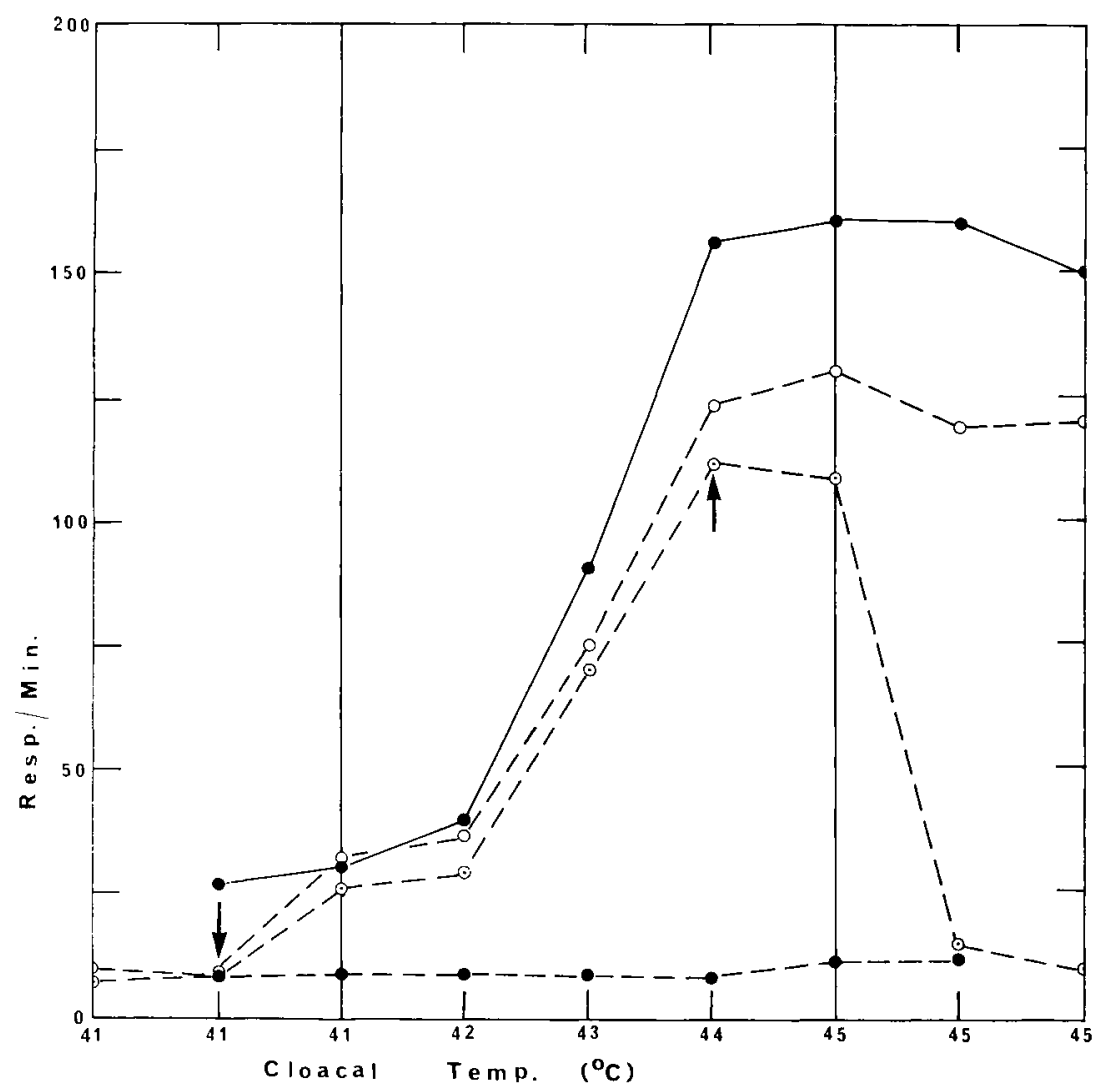

FIG. 4. - Changes in respiratory frequency in relation to bilateral vagotomy and afferent vagal stimulation in three fotels during progressive hyperthermia

- - Fowl $x$, control ; . . . . . . Fowl r, vagotomized ; o...... . Fowl r2, vagotomized; $0 . . . .$. . Fowl $\mathrm{I}_{3}$, vagotomized. Fowls $\mathrm{I}_{2}$ and $\mathrm{I}_{3}$ received electrical stimulation (parameters, I. $5 \mathrm{v}$; ro c/s; I ms) between the arrows. After stimulation, panting continued in $\mathrm{I} 2$ but collapsed in 13 . 
4-6/mn, as suggested by SAIT and ZEUTHEN (Ig60). In the pigeon, at least during hyperthermia, dependence upon vagal afferent drive is much less important and the " panting centre " of SAALFELD (I936) must be presumed capable of maintaining polypnoea by way of the medullary centres without essential impulses from receptors in the thorax.

In addition to investigations of the centres concerned specifically with respiration and panting, two studies have demonstrated a diffuse respiratory representation in the avian forebrain. Thus, stimulation of various striatal and thalamic nuclei (VEDyAev, I963) and the hyperstriatum (CoHEn and PitTs, I967) produced in some instances an acceleration in breathing frequencies to rates normally associated with polypnoea.

The relative importance of central and peripheral thermosensitivity is by no means settled even in mammals (BLIGH, I 666 ). Observations on the fowl placed under infra-red irradiation (RICHARDS, 9968 ) gave no indication that panting may be started by superficial warming of the skin in the absence of an increase in deep body temperature, nor as a conditioned reflex (HuTCHINSON, I954 b). This was also RANDALI.'s (I943 a) view after experiments in which skin temperature was raised while the carotid blood was maintained at or below the normal temperature of the body by means of a metal collar and circulating water; he thus concluded that polypnoea must be under discrete central control, i. e. secondary to a rise in the temperature of the brain. The onset of panting is, in fact, almost invariably associated with a small rise in body temperature in birds (KING and FARNER, I964), although Fi, HADr (I969) was able to demonstrate the start of panting in some of his fowls before a detectable increase. Nevertheless, the onset of polypnoeic breathing occurred only after several minutes in the hot ambient conditions, a finding which probably indicates the thermal inertia of the rectum as compared to the more important temperature of the brain, rather than any true peripheral initiation of panting. This conclusion is supported by the data of LINSLEY and BURGER (I964). Reflex inhibition of polypnoea (as a result of local or superficial cooling without a change in core temperature) has, however, been claimed as a result of subjection to a stream of cold air (RANDALL and HIESTAND, I943 $a$ ) or sudden transference to an ice chamber (RANDALI, I943 a), while STEEN and STEEN (I965) demonstrated a similar effect in panting gulls by cooling the legs. KAHL (I963), using the wood stork, reported that ' panting ' at 75 breaths $/ \mathrm{mn}$ fell abruptly to $36 / \mathrm{mn}$ with rapidly decreasing ambient temperatures. RANDALi, (I943 b) also claimed to have demonstrated lowering of the central panting temperature threshold by subjecting his birds to prolonged hypothermia prior to rapid warming, but these experiments have rightly been criticised by WHITTOW (I965) who noted that the skin temperature of the birds that had been cooled was higher during subsequent warming than was the case in birds that had not been cooled. This could have produced an enhancement of afferent nerve impulses which themselves may have lowered the panting threshold by facilitation of the thermoregulatory centre, much as occurs in some mammals (BLIGH, I966). The influence of peripheral receptors has, in fact, now been reported by HOWELI and BARTHOLOMEW (Ig62) who found that panting could occur in nestlings of the red-tailed tropic bird and gular fluttering in those of the red-footed booby, before detectable increases in deep body temperature, and this was subsequently confirmed by BARTHOLOMEW, (I966) for masked booby chicks of all sizes when exposed to direct solar radiation. 
Clearly there is a great need for repetition of some of the earlier experiments under more carefully controlled conditions and with more precise techniques.

III. - EFFECT OF PANTING ON THE ACID-BASF

\section{STATUS OF THE BLOOD}

It has often been suggested that the structure of the avian respiratory system, which provides for two separate pathways for air to reach the air sacs, one directly through the small parabronchi in the lung itself and another through the larger, direct mesobronchi, might be adapted to allow the exchange of large volumes of air for evaporative cooling without at the same time causing a wash-out of carbon dioxide

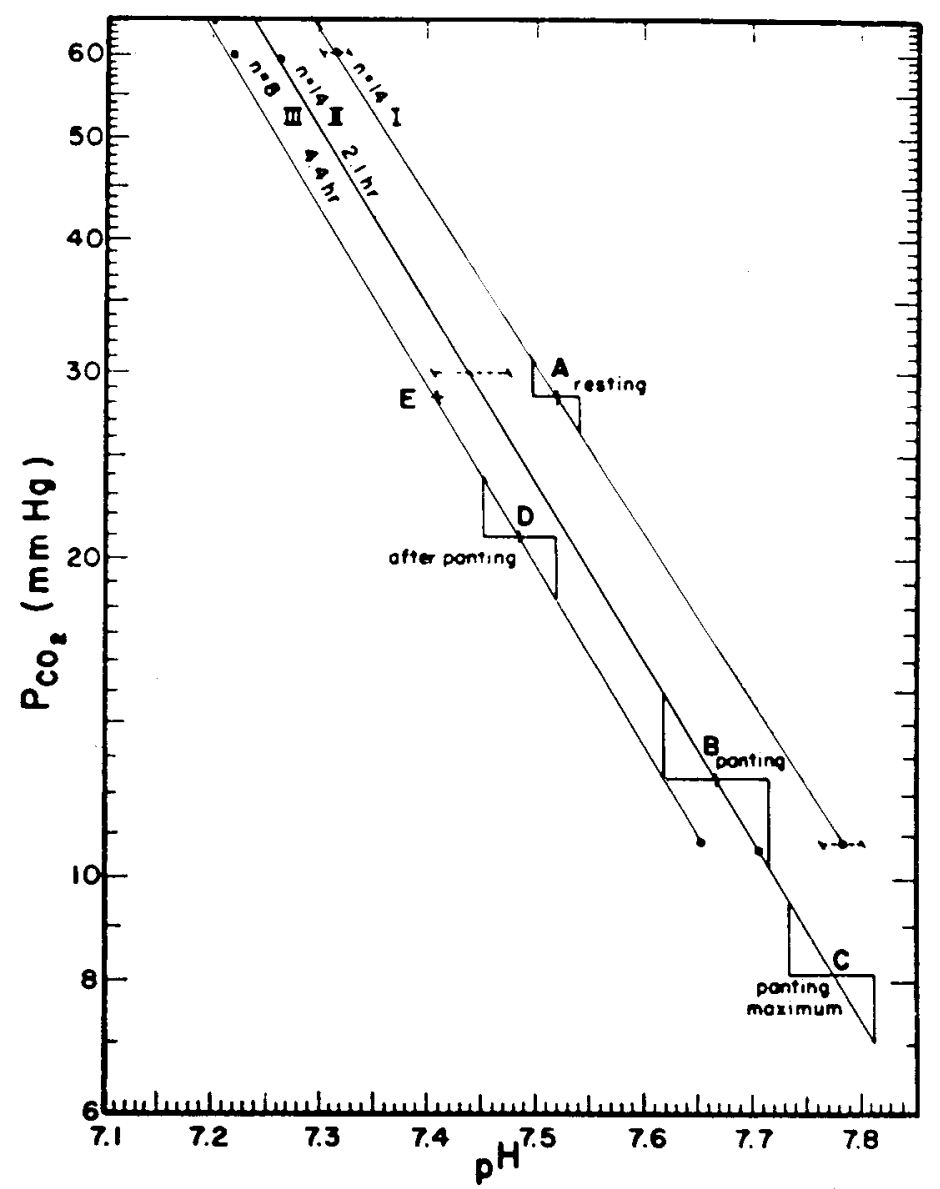

FIG, 5. - Equilibrium curves and mean blood $p \mathrm{H}$ and $\mathrm{pCO}_{2}$ values for non panting pigeons (curve I), during panting (curve II), and immediately following cessation of panting (curve III). The standard deviation for curves I and II is indicated by horizontal dotted lines. (After CALDER and SCHuIDT-NIELSEN, I966; courtesy Proc. nation. Acad. Sci. and authors.) 
from the lungs by excessive over-ventilation (ZEUTHEN, I942 ; HUTCHINSON I954 $b$; Salt and Zeuthen, ig6o ; King and Farner, I96I; Sal, I964). It was felt that the respiratory alkalosis sustained in panting mammals (ANREP and HAMmOUDA, I933; BiancA, I955; Higgins and IAMPETro, I967; Hales and Webster, I967) might thus be avoided.

Recent direct experimental evidence, however, has shown this supposition to be untenable; both in the pigeon and the fowl considerable alkalosis occurs during thermal panting. In figure 5, from CALDER and ScHMIDT-NIELSEN's (I966) work on the pigeon, point $\mathrm{A}$ on the control curve I represents the mean value and the standard deviation for the $\mathrm{pH}$ of the arterial blood of fourteen birds. Curve II is for birds after panting for between $\mathrm{I} 4 \mathrm{mn}$ and 6 hours at $48-54^{\circ} \mathrm{C}$, and shows the change in $\mathrm{pH}$ from a non panting mean of 7.52 to 7.69 , and of $\mathrm{pCO}_{2}$ from $28.5 \mathrm{~mm} \mathrm{Hg}$ to $\mathrm{I} 2.3 \mathrm{~mm}$ (point $\mathrm{B}$ ). The mean of the highest $\mathrm{pH}$ values for the birds is given at point $\mathrm{C}\left(\mathrm{pH}_{7}\right.$.79), and the corresponding lowest $\mathrm{pCO}_{2}$ value was $8.1 \mathrm{~mm}$. CALDER and SCHMIDT-NIELSEN showed that the shift of curve II to the left was not an artifact, nor due to temperature differences, but rather must have resulted from a change in the buffer system of the blood, perhaps by the addition of lactic acid or by the removal of base by the kidneys. Curve III represents data from eight of the pigeons after their return to a lower temperature. The shift to the left had continued further, the $\mathrm{pCO}_{2}$ increased to $2 \mathrm{I} .0 \mathrm{~mm}$ and $\mathrm{pH}$ to near the control value (point $\mathrm{D}$ ). Point $\mathrm{E}$ shows the $\mathrm{pH}$ value that would have been attained if $\mathrm{pCO}_{2}$ had returned to the control figure of $28.5 \mathrm{~mm}$. According to the authors' calculations (table $\mathrm{I}$ ), the decrease in $\mathrm{pCO}_{2}$ of the blood indicated a threefold increase in the passage of air over the gas exchange surfaces of the lung, even though the percentage of the total respiratory air flow passing over these surfaces was diminished.

In the fowl, LINSLEY and BURGER (I964) measured a profound respiratory alkalosis in cockerels exposed to $45^{\circ} \mathrm{C}$ ambient temperature and found the maximum rise in $\mathrm{pH}$ and fall in $\mathrm{pCO}_{2}$ and bicarbonate ion concentration to occur during the " second phase " panting, which indicated an increased parabronchial ventilation even after the decline from maximum frequency of breathing. MUELLER (Ig66), using White Leghorn pullets, described a small shift in the acid-base balance in the direction of respiratory alkalosis as a result of transferring his birds from $I 3^{\circ}$ to $34^{\circ} \mathrm{C}$ environmental temperature. FRANKE, and FrasceiL LA (Ig68) likewise showed with male birds of the same breed that thermal panting involves an increase in alveolar-arterial blood gas exchange. Arterial $\mathrm{pCO}_{2}$ fell from the control value of $26.0 \mathrm{mmHg}$ by more than II mm during exposure to a temperature of $40^{\circ} \mathrm{C}$, and $\mathrm{pH}$ increased from a mean of 7.46 at a rectal temperature of $4 \mathrm{I}^{\circ} \mathrm{C}$ to 7.66 at $45^{\circ} \mathrm{C}$. These changes were accompanied by hypocapnic lacticacidosis manifested in increases in the levels of blood lactate and pyruvate.

A summary of Eir HADI's (I969) work on hens of light breed is presented in figures 6 and 7 . His experiments involved three groups of birds : 5 unacclimatised fowls (previously kept at $\mathrm{I} 6-2 \mathrm{I}^{\circ} \mathrm{C}$ ) exposed to $37.8^{\circ} \mathrm{C}$ for 3 hours ; I5 unacclimatised fowls exposed to $40.5^{\circ} \mathrm{C}$ for 2 hours ; and 5 hens acclimatised to $37.8^{\circ} \mathrm{C}$ for four months prior to exposure to $40.5^{\circ} \mathrm{C}$ for 2 hours. The frequency of panting achieved was similar in the three groups but its efficiency was inadequate to prevent a rise in rectal temperature ; in addition, a respiratory alkalosis occurred in each case. The acclimatised birds exhibited an alkalosis $(\mathrm{pH}, 7.59)$ before being challenged at $40.5^{\circ} \mathrm{C}$ (thus 
showing no apparent evidence of renal compensation), and during the period of exposure their mean $\mathrm{pH}$ rose further to the same value (7.66) as that in the unacclimatised fowls at the same temperature. Corresponding alterations in arterial $\mathrm{pCO}_{2}$ and $\mathrm{HCO}_{3}$ were found in each group, although these occurred smoothly in the unacclimatised birds exposed to $40.5^{\circ} \mathrm{C}$, but by erratic fluctuations in the other two groups (fig. 7). El. HADI felt that this difference might reflect the dominance of the severe

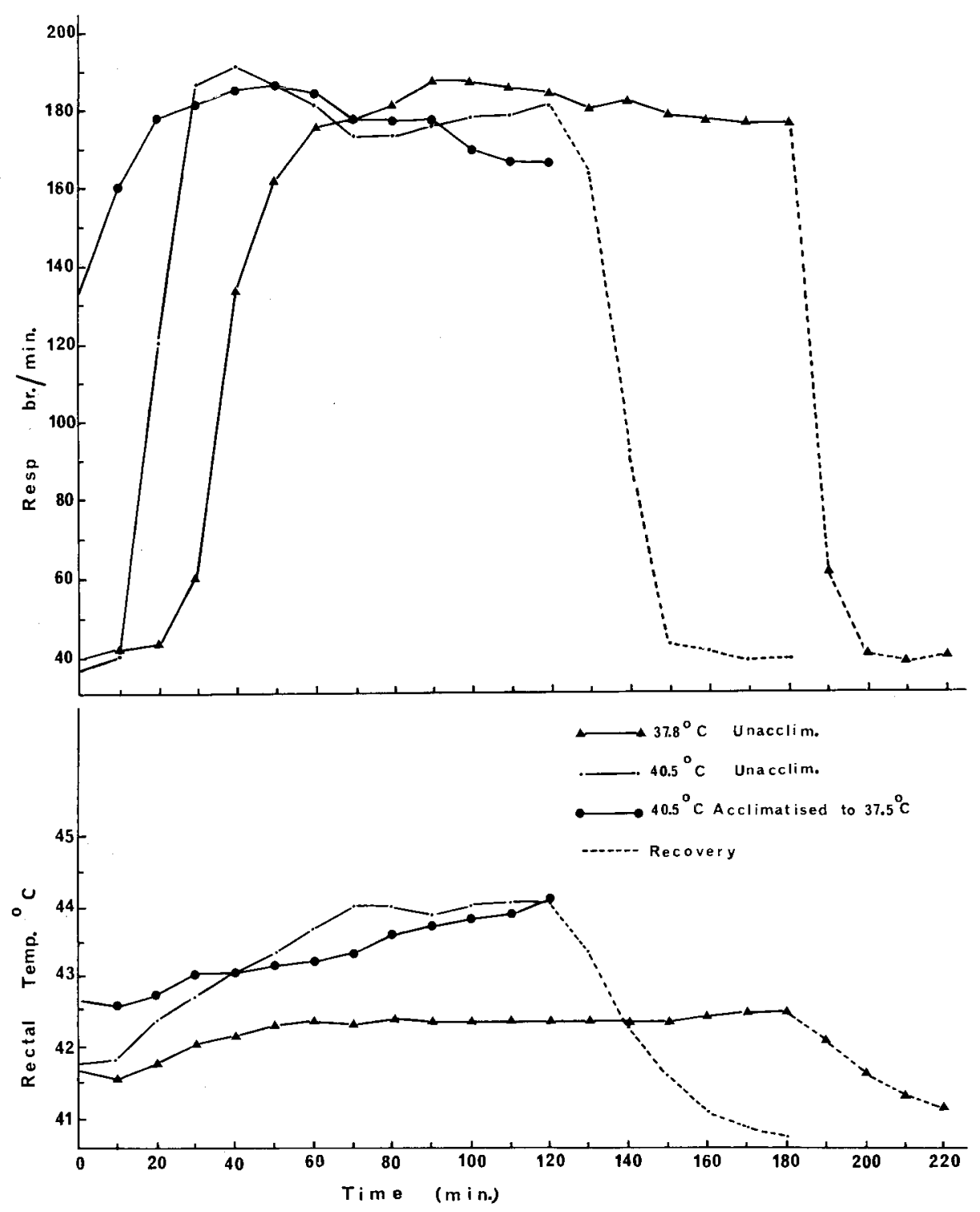

FIG. 6. - Effect on respiratory rate and rectal temperature of exposing fowls to $37.8^{\circ} \mathrm{C}$ (5 unacclimatized birds) and $40.5^{\circ} \mathrm{C}(15$ unacclimatized and 5 and 5 acclimatized birds) Recovery was at $16-21^{\circ} \mathrm{C}$. Mean values. (After EL HAd, I969, by permission). 
thermal stimulus in the first case (tending to increase ventilation) as compared to a conflict between temperature on the one hand and the $\mathrm{pH}$ and $\mathrm{pCO}_{2}$ changes, both of which tend to decrease respiration, on the other.

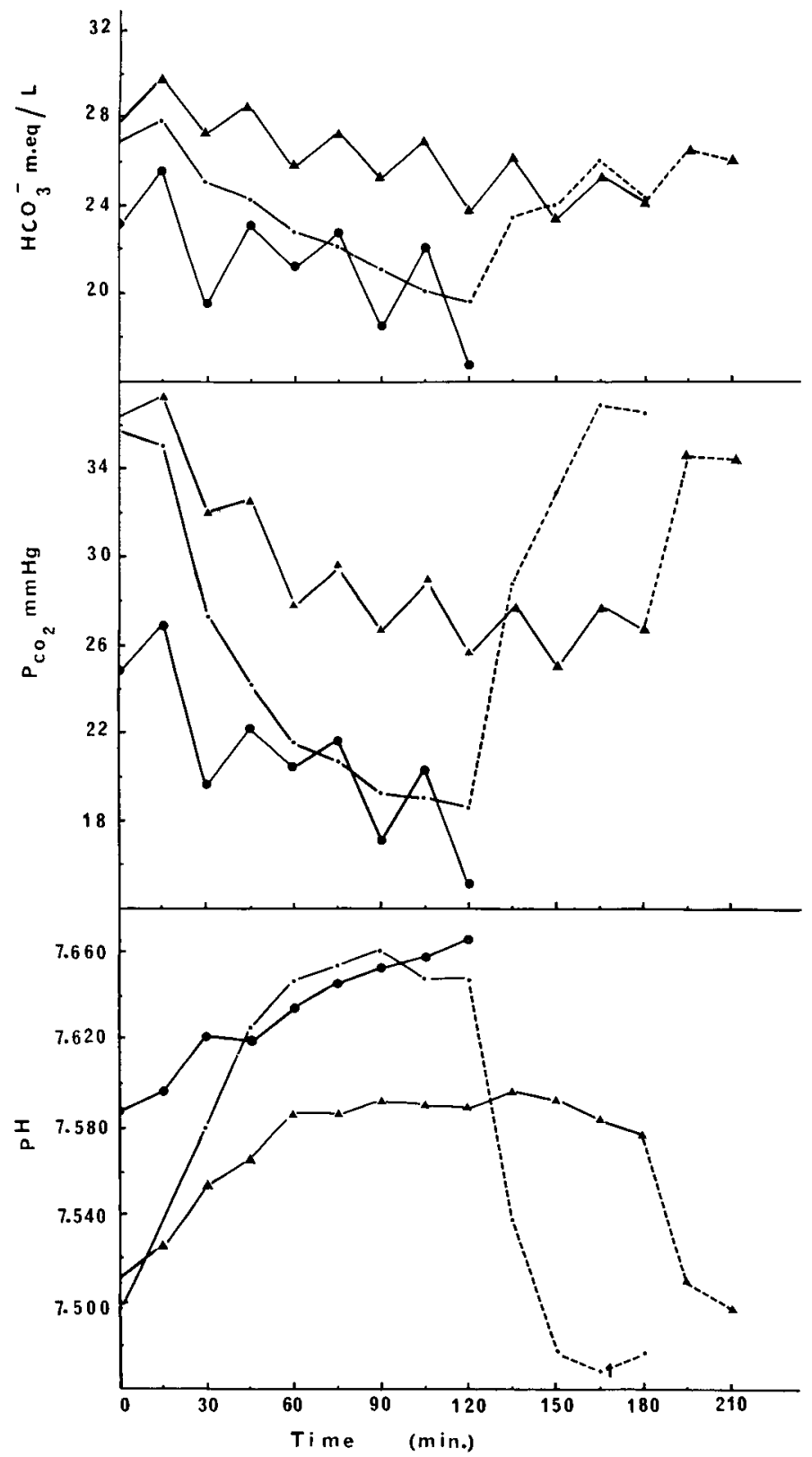

FIG. 7. - Effect on arterial blood $p H, p \mathrm{CO}_{2}$ and $\mathrm{HCO}_{3}$ of exposing fowls to high ambient temperatures Details as in Fig. 6. (After EL HADr, 1969, by permission) 


\section{SUMMARY}

An increase in respired air volume by rapid panting is the characteristic means of evaporative cooling in birds subjected to thermal stress. There are species differences with respect to changes in tidal volume during polypncea and to the rate of panting movements, which may occur either at a resonant frequency independent of body temperature or at non-resonant frequencies increasing with heat load. The air sacs may participate in heat loss but the unique anatomy of the avian respiratory system does not prevent the development of severe respiratory alkalosis during thermal polypnoea. Although tolerance of hyperthermia is widespread among birds, panting appears to be a relatively efficient method of thermoregulation.

Present evidence indicates that the respiratory adjustments involved in panting are organized by centres in the hypothalamus, midbrain and medulla; in some species panting appears dependent upon extrinsic stimuli mediated by way of the vagus nerves, but in the pigeon it is controlled by central mechanisms alone. The contribution of peripheral nervous components remains uncertain.

\section{RÉSUMÉ}

\section{PHYSIOLOGIE DU HALĖTEMENT THERMIQUE CHEZ LES OISEAUX}

L'augmentation du volume d'air respiré grâce à un halètement rapide est le moyen caractéristique de refroidissement par évaporation chez les oiseaux soumis à un excès de chaleur. Il existe des différences entre espèces tant pour les changements de débit ventilatoire pendant la polypnée que pour lc rythme des mouvements de halètement ; ces derniers peuvent être effectués soit à une fréquence résonnante indépendante de la température corporelle, soit à des fréquences non résonnantes qui augmentent avec la surcharge thermique. Il est possible que les sacs aériens contribuent à la perte de chaleur mais l'anatomie unique en son genre du système respiratoire aviaite n'empêche pas le développement d'une alcalose respiratoire sévère au cours d'une polypnée d'origine thermique. Bien que la tolérance à l'hyperthermie soit générale chez les oiseaux, le halètement semble être une méthode assez efficace de thermorégulation.

Les preuves acquises à ce jour indiquent que les ajustements respiratoires mis en jeu lors du halètement sont contrôlés par des centres situés dans l'hypothalamus, le cerveau moyen et la moelle ; chez quelques espèces, le halètement semble dépendre de stimuli extrinsèques transmis par les nerfs vagues, mais chez le pigeon il est contrôlé uniquement par des mécanismes centraux. La contribution de composants nerveux périphériques reste incertaine.

\section{REFERENCES}

Akermax B., Andersson 13., Fabricius E., Svensson L., ig6o. Observations on central regulation of body temperature and of food and water intake in the pigeon. Acta physiol. scand., 50, 328-336.

Anrep G. V., Hammouda M., 1933. Observations on panting. J. Physiol., 7y, 16-34.

Bartholonew G. A., ig6o. The physiology of desert birds. Anat. Rec., 137, 338.

Bartholonew G. A., I966. The role of behaviour in the temperature regulation of the masked booby. Condor, 68, 523-535.

Bartholomew G. A., Cade T. J., 1963. The water economy of land birds. Auk., 80, 504-539.

Bartholonew G. A., Dawson W. R., O'Neil E. J., r953. A field study of temperature regulation in young white pelicans, Pelecanus erythrorhynchus. Ecology, 34, 554-560.

Bartholomew G. A., Hudson J. W., Howell T. R., ig62. Body temperature, oxygen consumption, evaporative water loss, and heart rate in the poor-will. Condor, 64, Iry-125.

Bianca W., I955. The effect of thermal stress on the acid-base balance of the Ayshire calf. J.agric. Sci., 45, 428-430.

BIANCA WV., I958. The relation between respiratory rate and heart rate in the calf subjected to severe heat stress. J. agric. Sci., 51, $32 \mathrm{r}-324$. 
Bligh J., 1966. The thermosensitivity of the hypothalamus and thermoregulation in mammals. Bio. Rev., 41, 317-367.

Calder W. A., Schmidt-Nielsen K., I966. Evaporative cooling and respiratory alkalosis in the pigeon. Proc. Nation. Acad. Sci., 55, 750-756.

Calder W. A., Schmidt-Nielsen. K., I967. Temperature regulation and evaporation in the pigeon and the roadrunner. Amer. J. Physiol, 213, 883-889.

Conen D. H., Pitss L. H., 1967. The hyperstriatal region of the avian forebrain : somatic and autonomic responses to electrical stimulation. J. comp. Neurol., 131, 323-336.

Comroe J. H., 1965. Physiology of Respiration, 28-38, Year Book Medical, Publishers Inc., Chicago.

Cowles R. B., DAwson W. R., I95I. A cooling mechanism of the Texas nighthawk. Condor, 53, $19-22$.

Crawford E. C., I962. Mechanical aspects of panting in dogs. J. appl. Physiol., 17, 249-25x.

Crawford E. C., Schmidt-Nielsen K., I967. Temperature regulation and evaporative cooling in the ostrich. Amer. J. Physiol., 212, 347-353.

DAwson W. R., I958. Relation of oxygen consumption and evaporative water loss to temperature in the cardinal. Physiol. Zool., 31, 37-48.

Dawson W. R., Schmidt-Nielsen K., 1964. Terrestrial animals in dry heat: desert birds. Handbook of Physiology, Sec. 4, $48 \mathrm{I}-492$, Amer. Physiol. Soc., Washington, D. C.

EL. HADI H., I969. The acid-base status of the domestic fowl during thermal polypnoea. Ph D. thesis, University fo London.

FEDDE M. R., Burger R. E., Kitchell R., Ig6r. The influence of the vagus nerve on respiration Poultry Sci., 40, I4OI.

FEDDE M. R., BURger R. E., KITChell R. L., I963a. The effect of anaesthesia and age on respiration following bilateral cervical vagotomy in the fowl. Poultry Sci., 42, 1212-1223.

Fedde M. R., BURger R. E., Kitchell R. L., I963 b. Localization of vagal afferents involved in the maintenance of normal avian respiration. Poultry Sci., 42, 1224-1235.

Feldman S. E., Larsson S., Dimick M. K., Lepkovsky S., i957. Aphagia in chickens. Amer. J. Physiol., 191, 259-26I.

Findlay J. D., 1957. The respiratory activity of calves subjected to thermal stress. J. Physiol., 136 , 300-309.

Fischer G., Ig05. Vergleichend-anatomische Untersuchungen über den Bronchialbaum der Vogel. Zoologica, 19, I-45.

Frankel H., Frascelia O., I968. Blood respiratory gases, lactate, and pyruvate during thermal stress in the chicken. Proc. Soc. exp. Biol. Med., 127, 997-999.

Frankel H., Hollands K. G., Weiss H. S., ig62. Respiratory and circulatory responses of hyperthermic chickens. Arch. internat. Physiol. Biochim., 70, 555-563.

Hales J. R. S., Webster M. E. D., I967. Respiratory function during thermal tachypnoea in sheep. J. Physiol., 190, 24I-260.

Hammel H. T., I968. Regulation of internal body temperature. Ann. Rev. Physiol., 30, 64I-7Io.

Hardy J. D., I961. Physiology of temperature regulation. Physiol. Rev., 41, 52I-606.

HiEstand W. A., RANDAll W. C., I942. Influence of proprioceptive vagal afferents on panting and accessory panting movements in mammals and birds. Amer. J. Physiol., 138, I2-I5.

Higgins A. E., IAmpetro P. F., I967. Thermal panting and the initiation of respiratory alkalosis. Can. J. Physiol. Pharmacol., 45, I-I2.

Howell T. R., Bartholomew G. A., I962. Temperature regulation in the red-tailed tropic bird and red-footed booby. Condor, 64, 6-I8.

Hutchinson J. C. D., x954 a. Evaporative cooling in fowls. J. agric. Sci., 45, 48-59.

Hutchinson J. C. D., 1954 b. Heat regulation in birds. Progress in the Physiology of Farm Animals. Ed. Hammond J., 299-362. Butterworth, London

KAll M. P., I963. Thermoregulation in the wood stork, with special references to the role of the legs. Physiol. Zool., 36, 14I-I52.

Kanematsu S., Kil M., Sonada T., Kato Y., r967. Effects of hypothalamic lesions on body temperature in the chicken. Jap. J. vet. Sci., 29, 95-I04.

Kayser C., I930. Contribution à l'étude de la régulation thermique. Ann. Physiol. Physico. Chem. Biol., 6, 72I-744

KENDEIGH S. C., I944. Effect of air temperature on the rate of energy metabolism in the English sparrow. J. exp. Zool., 96, I-I6.

KING A.S., I966. Afferent path ways in the vagus and their influence on avian breating : a review. Physiology of the Domestic Forel. Ed. Horton-Smith, C. Amoroso, E. C., 302-310, Oliver and Boyd, London.

KING J. R., FARner D. S., I96i. Energy metabolism, thermoregulation and body temperature. Biology and Comparative Physiology of Birds. ed. Marshall, A. J., vol. 2, 215-288, Academic Press, London.

KING J. R., FARner D. S., I964. Terrestrial animals in humid heat : birds. Handbook of Physiology. Sec. 4, 603-624. Amer. Physiol. Soc., Washington, D. C. 
LAsiewsKI R. C., 1964. Body temperature, heart and breathing rate. and evaporative water loss in hummingbirds. Physiol. Zool., 31, $212-223$.

Lasiewski R. C., Acosta A. L., Bernstein M. H., ig66a. Evaporative water loss in birds. I. Comp. Biochem. Physiol., 19, 445-447.

Lasiewsiki R. C., Acosta A. L., Bernstein M. H., ig66 b. Evaporative water loss in birds. II. Comp. Biochem. Physiol., 19, 459-470.

Lasiewski R. C., Bartholomew G. A., I966. Evaporative cooling in the poor-will and tawny frogmouth. Condor, 68, 253-262.

Lasiewsin R. C., Dawson W. R., I964. Physiological responses to temperature in the common nighthawk. Condor, 66, 477-49o.

Linsley J. G., Burger R. E., I964. Respiratory and cardiovascular responses in the hyperthermic domestic cock. Poultyy Sci., 43, 29I-305.

Mueller W. J., I966. Effect of rapid temperature changes on acid-base balance and shell quality. Poultry Sci., 45, rrog.

Randali W. C., I943a. Factors influencing the temperature regulation of birds. Amer. J. Physiol., $139,56-63$

RANDALL W. C., I 943 b. Alterations in response to changing body temperature following artifical fever and chilling. Proc. Soc. exp. Biol. Med., 52, 240-242.

Randall. W. C., Hiestand W. A., I939. Panting and temperature regulation in the chicken. Amer. J. Physiol., 127, 76r-767.

Randall W. C., Hiestand W. A., I942. Comparison of the role of afferent vagal proprioceptive fibers in respiratory control in birds and mammals. Anat. Rec., 84, 532-533.

Richards S. A., I968. Vagal control of thermal panting in mammals and birds. J. Physiol. 199, 89-IOI.

Richards S. A., I969. Vagal function during respiration and effects of vagotomy in the fowl. (Gallus domesticus Comp. Biochem. Physiol., 29, 955-964.

Richet C., 1898. Dictionnaire de Physiologie, vol. 3, 175-180. Germer-Baikiere, Paris.

Rogers F. T., I9Ig. Studies on the brain stem. I. Regulation of body temperature in the pigeon aud its relation to certain cerebral lesions. Amer. J. Physiol., 49, 27x-283.

ROGERS F. T., I928. Studies on the brain stem. II. The effects of artificial stimulation and traumatization of the avian thalamus. Amer. J. Physiol., 86, 639-650.

Rogers F. T., Wheat S. D., I92I. Studies on the brain stem. V. Carbon dioxide excretion after destruction of the optic thalamus and reflex functions of the thalamus in body temperature regulation. Amer. J. Physiol., 57, 2 I8-227.

Romijs C., Lokhorst W., I96I. Climate and poultry. Heat regulation in the fowl. Tidjdschr. Diergeneesk, 86, I53-172.

SAALFELD E. von, I936. Untersuchungen über das Hacheln bei Tauben. Z, vergl. Physiol., 23, $727-743$.

Saint-Paul U. von, Aschoff J., I968. Gehirntemperaturen bei Huhnern. Pfugers Arch. Ges. Physiol., 301, 109-123.

SAlt G. W., I964. Respiratory evaporation in birds. Biol. Rev., 39, II3-I36.

Salt G. W., ZeUthen E., I960. The respiratory system. Biology and Comparative Physiology of Birds. ed. Marshall, A. J., vol. 1, 363-409. Academic Press, London.

Sinha M. P., I958. Vagal control of respiration as studied in the pigeon. Helv. Physiol. Acta, 16, 58-72.

SinhA M. P., I959. Observations on the organization of the panting centre in avian brain. Int. Cong. Physiol. Sci. (abstracts), Buenos Aires, 254.

Steen I., Steen J. B., I965. The importance of the legs in thermoregulation of birds, Acta Physiol. scand., 63, 285-29x.

VedyaEV F. P., I963. The role of structures at the striatal and thalamic levels of the CNS in the regulation of respiration and their functional characteristics in birds. Fiziol. $Z h$. S. S. S. R. Seckenova, 49$666-676$.

Wallgren H., 1954. Energy metabolism of two species of the genus Emboriza as correlated with distribution and migration. Acta Zool. Fennica, 84, I-I Io.

WaNG S. C., Ngai S. H., rg64. General organization of central respiratory mechanisms. Handbook of Physiology, Sec. 3, Vol. 1, 487-505, Amer. Physiol. Soc., Washington. D. C.

Whitsow G. C., I965. Regulation of body temperature.. Avian Physiology, ed. Sturkie, P. D., I86238, Baillière, Tindall and Cassel, London.

Whittow G. C., Sturkie P. D., Stein G., I964. Cardiovascular changes associated with thermal polypnoea in the chicken. Amer. J. Physiol., 207, 1349-I353.

ZEUTHEN E., I942. The ventilation of the respiratory tract in birds. Kgl, Danske Videnskab. Selskab. Biol. Nedd. 17, I-50. 